\title{
WORKPLACE ISOLATION: A SYSTEMATIC REVIEW AND SYNTHESIS
}

\author{
Shikha Sahai, Mariam Anil Ciby, Ahmad Taha Kahwaji \\ Assistant Professor, Department of Management, College of Commerce and \\ Business Administration, Dhofar University, Salalah, Oman
}

\begin{abstract}
With the rising popularity of telecommuting and other new forms of work arrangements, workplace isolation has gained relevance in recent times. Nevertheless, workplace isolation can also occur amongst employees in traditional work settings too. Empirical evidences suggest that workplace isolation has a relationship with employee attitude, behavior, performance and well-being. Despite the prevalence and importance of workplace isolation, the literature on the concept, measurement, factors that influence it and how it influences outcome variables is dispersed. This article offers a systematic review of literature on workplace isolation, collating and synthesizing existing literature and also setting agenda for future research. In doing so we hope that it would attract interest of other scholars and eventually expand this body of research.
\end{abstract}

Key words: Workplace isolation; telework; telecommuting; social isolation at work; review on isolation.

Cite this Article: Shikha Sahai, Mariam Anil Ciby, Ahmad Taha Kahwaji, Workplace Isolation: A Systematic Review and Synthesis, International Journal of Management, 11(12), 2020, pp 2745-2758.

http://iaeme.com/Home/issue/IJM?Volume=11\&Issue $=12$

\section{INTRODUCTION}

The concept of telecommuting was introduced way back in the 1970s (Nilles, 1975). Some organizations introduced telecommuting as a form of work arrangement, while the majority of the organizations considered it as a future form of work. With the advent of global pandemic Covid-19, the organizations adjusted and adapted to telecommuting as the new normal. Several advantages of telecommuting have been reported. To individuals, it has provided a flexible work schedule, better work life balance and reduced inconvenience of commuting (Kurland \& Bailey, 1999; Mann, Varey, \& Button, 2000). To the organizations, it has enabled continuity of business during Covid-19, improved operational cost effectiveness and expanded labor market (Baruch, 2000; ILO, 2020). However, there are some concerns related to this work arrangement. It can lead to social isolation, longer hours of work, career stagnation, and workfamily conflict (Cooper \& Kurland, 2002; Delanoeije, Verbruggen, \& Germeys, 2019; Gajendran \& Harrison, 2007; Golden, Veiga, \& Dino, 2008; ILO, 2020; Mann et al., 2000). 
Amongst the various disadvantages, social isolation is the foremost concern of this work arrangement (Gainey, Kelley \& Hill, 1999; Huws, 1984; Mann et al., 2000).

Although workplace isolation can occur in telecommuting employees, its prevalence has also been reported among employees who work in traditional work settings (Bunjak \& Crene, 2018; Garcia, Bentein, Herrbach \& Guerrero, 2017; Marshall, Michaels, \& Mulki, 2007).

\subsection{Why is the Current Study undertaken?}

Social isolation is understood as individuals being separated from a group (Dean, 1961), and it occurs when "desire of support, understanding and other social and emotional aspects of interaction are not been met" (Taha \& Caldwell, 1993, p. 277). There is sufficient scientific evidence on isolation in the field of psychology, sociology and epidemiological sciences (see review by Abad, Fearday, \& Safdar, 2010; meta-analysis by Holt-Lunstad, Smith, Baker, Harris, \& Stephenson, 2015; Nicholson, 2012). However, this body of research is relatively underexplored in organizational studies. There is a call for considering theoretical and empirical framework for isolation in both traditional and virtual work settings (Bunjak \& Crene, 2018). There has been some development in workplace isolation literature in the last two decades. However, to the best of our knowledge, there is no systematic review currently available that examines isolation in the work domain. We intend to address this gap.

Given the prevalence of isolation in both traditional and modern work arrangements and the absence of an integrated understanding of workplace isolation, our review is timely and much warranted.

\subsection{Focus of the Current Study}

This study presents the findings of a systematic review of empirical literature on isolation at work and proposes a framework within which the existing body of research can be understood and classified. The overarching aim of this review is to address the questions: what is the empirical evidence-base concerning workplace isolation and how can this inform theory and practice in the world of work. Below mentioned are the sub-themes:

- How has workplace isolation been defined in the empirical studies?

- How has workplace isolation been measured in the empirical studies?

- What evidence is there concerning the antecedents and outcomes of workplace isolation?

- What evidence is there concerning mediators and moderators of workplace isolation and its antecedent/ outcome relationships?

We first discuss the methodology adapted to extract the relevant literature from various databases. We then address each of the research questions mentioned above, present the evidence-based existing framework of workplace isolation literature and suggest scope for future work to expand this body of knowledge.

\section{METHODOLOGY}

This study used the five-stage procedure recommended by Briner and Denyer (2010) for systematic review of the empirical literature. In the first stage (planning the review), four research questions (mentioned above) were formulated, key terms for searching databases were identified and scope of search was refined. Search of database was done using wide range of key terms like "social isolation", "professional isolation", "physical isolation", "isolation" AND "work", "isolation" AND "employees", "isolation" AND "virtuality", "isolation" AND "virtual work", "isolation" AND telecommuting", "isolation" AND "telecommuters", to ensure that important literature was not omitted. We highlight here that the scope of our review was 
limited to 'workplace isolation' only which is conceptually different from some related but distinct variables, like workplace loneliness and workplace alienation.

In the second stage (locating studies), we searched across four databases: Proquest, EBSCO, Google scholar and Research gate. We used a variety of search strings (mentioned above) to cast a wide net while searching the available database. The initial search resulted in 450 research articles. The search was further refined by confining it to the following criteria: a) isolation in work studies were only included b) studies which discussed/ evaluated some aspect of isolation like antecedent, outcomes, mediators, moderators were included c) studies in which workplace isolation was examined either as a key variable or as a co-variable were also included. This resulted in 92 studies. In the third stage (appraising contribution), the abstract of the 92 studies were read to decide the inclusion of the research for the existing review. This resulted in 28 studies. To this, 5 further studies were added by manual tracking of the citation mentioned in the short-listed research papers. We finally included 33 studies in the current review. In the fourth stage (analyzing and synthesizing information) each research paper was reviewed and data from the same were extracted in a pro forma that was based on four research questions. The extracted data was analyzed with respect to the research questions and a detailed summary table was developed. In the last stage (reporting best evidence) a comprehensive overview of the findings was prepared, the report was organized into sub-themes that captured, categorized and reflected the complexity of the existing evidence and paved the path for future research. Output of this evidence-based overview is presented in the current paper.

\section{RESULTS}

\subsection{Overview of the Included Studies}

Of the 33 papers reviewed, $18 \%$ used a qualitative method and $78 \%$ used a quantitative method and $3 \%$ used a mixed method of study. Cent percent quantitative studies reviewed in this paper were cross-sectional in nature. Majority of the studies were conducted in US (39\%), followed by Canada (12\%), UK (9\%), Taiwan (6\%), Turkey (6\%), Ireland (3\%), New Zealand (3\%), Pakistan (3\%), Sweden (3\%), North American countries $(6 \%)$ and from multiple countries (9\%). Sample population for $60 \%$ of the studies was telecommuters and $40 \%$ was nontelecommuters. We now present the findings of our review.

Several researchers indicate that telecommuting options of working can cause workplace isolation (Mann et al., 2000; Cooper \& Kurland, 2002; Kurland \& Cooper, 2002). Professional isolation is higher for telecommuters as compared to non-telecommuters (Harrington \& Santiago, 2006). Isolation can occur amongst those who work in traditional office work-setting too (Marshal et al. 2007; Bunjak \& Crene, 2018). Researchers also indicate that mere nature of profession (teachers especially music teachers, adjunct faculty, principal, internal auditors, dirty work, salesperson, nurses) or belonging to a marginalized group (like migrant workers, LGBT community) can also cause isolation (Dolan, 2011; Dussault \& Barnett, 1996; McFadden \& Crowley-Henry, 2018; Mulki \& Jaramillo, 2011; Mulki, Locander, Marshall, Harris, \& Hensel, 2008).

\subsection{Definition of Workplace Isolation}

Marshall defined workplace isolation as "lack of satisfying friendship relationships or a lack of access to social networks in workplace" (Marshall et al., 2007, p. 198). This is one of the widely used definition in the literature. Golden et al. (2008) widened this definition as lack of sufficient professional and social contact at workplace. Scholars suggest that workplace isolation among telecommuting workers can be of two types: professional isolation and social isolation (Cooper \& Kurland, 2002; Kurland \& Cooper, 2002). Professional isolation is defined as reduced opportunity of promotion and other rewards that are available in the organization (Kurland \& 
Bailey, 1999) and social isolation is the deprivation of informal interactions and relationships with colleagues and friends in the organization (Cooper \& Kurland, 2002; Kurland \& Cooper, 2002). Physical isolation is yet another type of workplace isolation identified from the literature. Physical isolation is defined as "employees' experience of working in settings in which they are not co-located with fellow organization members" (Bartel, Wrzesniewski, \& Wiesenfeld, 2012, p. 744).

We argue that though there are differences in these terms, but these isolation perceptions are intertwined. Several scholars' support our argument, for e.g., Cooper and Kurland (2002) indicated that difference between social isolation and professional isolation may be misleading as social isolation at work will lead to professional isolation. Similarly, Kane (2014) argued that physical isolation, social isolation and professional isolation are intricately linked. We refer to all these isolation as workplace isolation. In our current review, we have collated studies referring to all the types of isolation that can occur at work. Table 1 presents the characteristics and studies that have evaluated various dimensions of workplace isolation.

Based on our review, we define workplace isolation as a five-dimensional construct- lack of social support, lack of social interaction, lack of learning opportunity, lack of developmental opportunities and presence of physical isolation.

Table 1 Proposed Five Dimensions of Workplace Isolation

\begin{tabular}{|c|c|c|}
\hline Dimension & Characteristic & References \\
\hline $\begin{array}{l}\text { 1. Social } \\
\text { Support } \\
\text { Isolation }\end{array}$ & $\begin{array}{l}\text { Lack of support } \\
\text { from peers } \\
\text { /supervisor/ } \\
\text { organization }\end{array}$ & $\begin{array}{l}\text { Bentley, Teo, McLeod, Tan, Bosua, \& Gloet, 2016; Bostanci, 2013; } \\
\text { Bunjak \& Crene, 2018; Chen \& Kao, 2012; Davis \& Cates, 2013; } \\
\text { Dussault \& Barnett, 1996; Garcia, et al., 2017; Golden, et al., 2008; } \\
\text { Itani, Jaramillo, \& Chonko, 2019; Johnson, Hall, \& Theorell, 1989; } \\
\text { Mann et al. 2000; McFadden \& Crowley-Henry, 2018; Mulki et al., } \\
\text { 2008; Mulki \& Jaramillo, 2011; Munir, Sadiq, Ali, Hamdan, \& } \\
\text { Munir, 2016; O'Donnell, Jabareen, \& Watt, 2010; Riggle, 2007; } \\
\text { Riggle, Solomon, \& Artis, 2015; Sulu, Ceylan, \& Kaynak, 2010; } \\
\text { Wang, Albert \& Sun, 2020; Yang, } 2017\end{array}$ \\
\hline $\begin{array}{l}\text { 2. Social } \\
\text { Interaction } \\
\text { Isolation }\end{array}$ & $\begin{array}{l}\text { Lack of } \\
\text { informal/social } \\
\text { and emotional } \\
\text { interaction/ } \\
\text { deficient social } \\
\text { networks }\end{array}$ & $\begin{array}{l}\text { Barnett, 1996; Bostanci, 2013; Cooper \& Kurland, 2002; Davis \& } \\
\text { Cates, 2013; Dolan 2011; Dussault \& Dussault, Deaudelin, Royer, \& } \\
\text { Loiselle, 1999; Gallatin, 2018; Garcia et al. 2017; Golden et al., } \\
\text { 2008; Harrington \& Santiago, 2006; Johnson et al., 1989; Kane, } \\
\text { 2014; Kurland \& Cooper, 2002; Liston-Heyes \& Juillet, 2019; } \\
\text { Mangles, Khanin, \& Guzman, 2016; Mulki et al. 2008; Munir et al., } \\
\text { 2016; Orhan, Rijsman, \& Van Dijk, 2016; Riggle, 2007; Wang et al., } \\
\text { 2020 }\end{array}$ \\
\hline $\begin{array}{l}\text { 3. Professional } \\
\text { Learning } \\
\text { Opportunity } \\
\text { Isolation }\end{array}$ & $\begin{array}{l}\text { Lack of } \\
\text { information/ } \\
\text { lack of } \\
\text { opportunity to } \\
\text { learn }\end{array}$ & Cooper \& Kurland, 2002; Orhan, et al. 2016 \\
\hline $\begin{array}{l}\text { 4. Professional } \\
\text { Growth } \\
\text { Isolation }\end{array}$ & $\begin{array}{l}\text { Lack of } \\
\text { opportunity for } \\
\text { professional } \\
\text { advancement }\end{array}$ & $\begin{array}{l}\text { Dolan, 2011; Harrington \& Santiago, 2006; Kane, 2014; Kurland \& } \\
\text { Cooper, 2002; Munir et al., } 2016\end{array}$ \\
\hline $\begin{array}{l}\text { 5. Physical } \\
\text { Isolation }\end{array}$ & $\begin{array}{l}\text { Physical } \\
\text { isolation }\end{array}$ & $\begin{array}{l}\text { Bartel et al., 2012; Dolan, 2011; Garcia et al., 2017; Kane, 2014; } \\
\text { Orhan et al., 2016; Mangles et al., 2016; Riggle, 2007; Wang et al., } \\
2020\end{array}$ \\
\hline
\end{tabular}




\subsection{Measures}

The quantitative studies $(\mathrm{n}=27)$ reviewed in this article used multiple measures to examine workplace isolation. In this review, we present a comprehensive picture of all the measures that have been used in the workplace isolation studies (Table 2).

Table 2 Comprehensive Presentation of Workplace Isolation Measures

\begin{tabular}{|c|c|c|c|}
\hline $\begin{array}{l}\text { Name of the } \\
\text { Dimension }\end{array}$ & Measure & $\begin{array}{l}\text { Cronbach } \\
\text { alpha } \\
\text { reliability }\end{array}$ & References \\
\hline \multirow[t]{4}{*}{$\begin{array}{l}\text { Workplace } \\
\text { isolation }\end{array}$} & $\begin{array}{l}10 \text {-item workplace isolation scale } \\
\text { by Marshall et al., } 2007\end{array}$ & $0.73-0.92$ & $\begin{array}{l}\text { Chen \& Kao, 2012; Davis \& } \\
\text { Cates, 2013; Itani et al., 2019; } \\
\text { Marshall et al, 2007; Mulki et al. } \\
\text { 2008; Mulki \& Jaramillo, 2011; } \\
\text { Munir et al., 2016, Riggle, 2007; } \\
\text { Riggle et al., 2015; }\end{array}$ \\
\hline & $\begin{array}{l}\text { 10-item selected from } 65 \text {-item } \\
\text { identified by Marshall et al. , } 2007\end{array}$ & 0.84 & Orhan et al., 2016 \\
\hline & $\begin{array}{l}\text { 3-item Sense of isolation scale by } \\
\text { Connaughton \& Daly, } 2004\end{array}$ & 0.84 & Bunjak \& Crene, 2018 \\
\hline & $\begin{array}{l}\text { 20-item French version of revised } \\
\text { UCLA Loneliness scale by } \\
\text { Russell, Peplau \& Cutrona,1980; } \\
\text { 10-item modified UCLA } \\
\text { Loneliness Scale by Russell, } \\
\text { 1996; 6-item DJGLS loneliness } \\
\text { scale by De Jong Gierveld \& Van } \\
\text { Tilburg, } 2006\end{array}$ & $0.87-0.91$ & $\begin{array}{l}\text { Dussault \& Barnett, 1996; } \\
\text { Dussault et al., 1999; Mangles et } \\
\text { al., 2016; Stephenson \& Bauer, } \\
2010\end{array}$ \\
\hline \multirow[t]{4}{*}{$\begin{array}{l}\text { Social } \\
\text { Isolation }\end{array}$} & $\begin{array}{l}\text { 3-item friendship scale by } \\
\text { Hawthrone, } 2006\end{array}$ & 0.78 & Garcia et al., 2017 \\
\hline & $\begin{array}{l}\text { 7-item social isolation scale } \\
\text { derived from Leiter, } 1985 \text { and } \\
\text { Yang, Yang, and Kawachi, } 2001\end{array}$ & 0.90 & Sulu et al., 2010 \\
\hline & $\begin{array}{l}\text { 16-item Turkish version of Social } \\
\text { friendship at work scale by } \\
\text { Doğan, Çetin \& Sungur, } 2009\end{array}$ & 0.88 & Bostanci, 2013 \\
\hline & $\begin{array}{l}\text { 5-item work social support scale } \\
\text { developed for the study }\end{array}$ & 0.75 & Johnson et al., 1989 \\
\hline \multirow[t]{3}{*}{$\begin{array}{l}\text { Professional } \\
\text { Isolation }\end{array}$} & $\begin{array}{l}\text { 4-item scale by Teo, Lim, \& Wai, } \\
1998\end{array}$ & 0.80 & Harrington \& Santiago, 2006 \\
\hline & $\begin{array}{l}\text { 5-item professional isolation scale } \\
\text { adapted from Van Acker et al., } \\
2015\end{array}$ & 0.72 & Liston-Heyes \& Juillet, 2019 \\
\hline & $\begin{array}{l}\text { 7-item scale by Golden et al., } \\
2008\end{array}$ & $0.89-0.91$ & $\begin{array}{l}\text { Bentley et al., 2016; Golden et al. } \\
\text { 2008; Kane, } 2014\end{array}$ \\
\hline $\begin{array}{l}\text { Physical } \\
\text { isolation }\end{array}$ & $\begin{array}{l}\text { 1-item scale developed for the } \\
\text { study }\end{array}$ & N.A. & Bartel et al., 2012 \\
\hline $\begin{array}{l}\text { Professional } \\
\text { and Physical } \\
\text { Isolation }\end{array}$ & $\begin{array}{l}\text { 5-item scale of Golden et al., } 2008 \\
\text { to measure professional isolation } \\
\text { and } 1 \text {-item scale of Bartel et al., } \\
2012 \text { to measure physical } \\
\text { isolation }\end{array}$ & 0.84 & Wang et al., 2020 \\
\hline
\end{tabular}




\subsection{Antecedents of workplace isolation/ workplace isolation as mediator}

Amongst the papers reviewed, several antecedents of workplace isolation have been identified. We have categorized the antecedents identified in the review into: work environment related, leadership/ supervisor related and job resources related.

\subsubsection{Work Environment Related}

There is growing research evidence that several organizational variables can impact workplace isolation. Bostanci (2013) found that higher level of organizational responsiveness reduces workplace isolation. Riggle et al. (2015) found that perceived organization support reduces workplace isolation. Further to this, Bentley et al. (2016) found that when perceived support (perceived organizational support and perceived social support) is high, workplace isolation is less and workplace isolation in turn mediates the relationship between perceived support and psychological strain and job satisfaction. Gallatin (2018) in a qualitative research concluded that coworker support can reduce the perception of workplace isolation amongst consultants who telework. Harrington and Santiago (2006) concluded that hierarchical and rational organization culture reduced professional isolation for telecommuters.

Stephenson and Bauer (2010) found that perceived work environment (measured by role ambiguity, role overload, role conflict, social support and participation in formal training program) impacts social isolation i.e. if the perceived work environment is negative the social isolation is high and social isolation in turn leads to physical and emotional burnout. In a similar vein, O'Donnell et al. (2010) found that perceived positive work environment (working in groups, opportunity to use qualification and training and productive appraisal) reduces isolation, which in turn would increase intention to continue to work amongst nurses. Itani et al. (2019) found that ethical climate reduces workplace isolation and workplace isolation of colleagues partially mediated the relationship between ethical climate and job satisfaction relationship amongst salesperson. Organizational injustice also has been found to be an antecedent of social isolation. Sulu et al. (2010) in their research on doctors and nurses found that organizational injustice (distributive injustice and procedural injustice) leads to social isolation. Dolan (2011) in their research concluded that lack of communication from administration, lack of information on updates of priorities of institution, lack of feedback and lack of events that connect them with other faculty create a sense of isolation amongst adjunct faculty members.

\subsubsection{Leadership/Supervisor and Coworker Related}

Studies have also examined the role of supervisor and coworker on perceived workplace isolation. Kurland and Cooper (2002) found that supervisors use of 'managing by results' may enhance the perception of professional isolation amongst telecommuters. They also concluded that employee isolation and management control are inextricably linked. Munir et al. (2016) found that transformational leadership and interpersonal trust reduce perceived workplace isolation amongst sales person in pharmaceutical companies. In yet another research on salesperson in pharmaceutical companies, Mulki and Jaramillo (2011) found that considerate leadership reduced the perception on workplace isolation. This is indicative of the importance of supervisor's role in reducing the deleterious effect of workplace isolation. Gallatin (2018) in a qualitative research concluded that supervisor and high trust between teleworker and supervisor can reduce the perception of workplace isolation amongst consultants who teleworkers.

Bunjak and Crene (2018) found that leader's defensive pessimism and follower's defensive pessimism have an impact on follower's perceived isolation. They found that when there was congruence in the defensive pessimism of leader and follower the perceived social isolation 
was less and follower's perceived social isolation was high when follower's defensive pessimism was higher than leader's defensive pessimism. In yet another research, Yang (2017) found that supervisor's cultural intelligence had a negative impact on subordinate's workplace isolation and LMX mediates the relationship. They further concluded that workplace isolation mediates the relationship between LMX and well-being. Coworker communication and perception of not having meaningful conversation with colleagues can also cause workplace isolation amongst teleworkers (Gainely et al., 1999; Gallatin, 2018).

\subsubsection{Job/ Task Related}

Researchers have also examined the impact of job characteristics on workplace isolation. Kurland and Cooper (2002) found that the job characteristic itself (i.e., telecommuting) reduces the opportunity for informal learning, networking and mentoring, which in turn impedes professional development and increases the perception of professional isolation. Chen and Kao (2012) concluded that job resources (possibility of career development and peer support) had a significant negative relationship with isolation. In a study on teleworkers, Orhan et al. (2016) found that with increase in task virtuality workplace social isolation also increases. Kane (2014) found that frequency of telework had an impact on professional isolation.

Another group of variables that has been explored as an antecedent is focus on developmental activities. Dussault and Barnett (1996) in their research on educational managers concluded that peer assisted developmental program reduced professional isolation. Cooper and Kurland (2002) in a qualitative research concluded that perceived availability of the developmental activities (mentoring, informal learning and interpersonal networking) negatively impacted professional isolation. They further concluded that the relationship between developmental activity and professional isolation was moderated by extent to which developmental activities were valued by the organization and extent to which these activities are available to telecommuters. In yet another qualitative research, Kurland and Cooper (2002) found that there is an increased perception of professional isolation when employees are expecting a promotion. Dolan (2011) found that lack of opportunity to learn and develop skills can cause isolation amongst adjunct faculty members. Knowledge of these antecedents can enable organization to develop strategies to reduce workplace isolation and its deleterious effects on individual, team and organization.

\subsection{Outcomes of Workplace Isolation/ Mediators of Workplace Isolation and Outcome Relationship}

There is evidence showing that workplace isolation has influence on variety of outcomes in different levels of analysis including individual affect, attitude, behavior, performance and well-being.

Relationship has been indicated between workplace isolation and affect - reduced affective bond, emotional contagion for new assignment, loneliness, loss of social barometer for comparison leading to reduced confidence (Mann et al., 2000); burnout (Stephenson \& Bauer, 2010), emotional exhaustion (Garcia et al., 2017);

Studies have also established relationship between workplace isolation and several employee attitudes like job satisfaction (Riggle, 2007; Bentley et al., 2016; Orhan et al., 2016; Itani et al. 2019); satisfaction with supervisor (Mulki et al., 2008; Mulki \& Jaramillo, 2011); satisfaction with coworker (Mulki et al., 2008); work group identity (Kane, 2014); organizational identification (Bartel et al., 2012; Kane, 2014), organizational commitment (Riggle, 2007; Mulki et al., 2008; Sulu et al., 2010), affective commitment (Wang et al., 2020); continuance commitment (Wang et al., 2020), engagement (Davis \& Cates, 2013; Garcia et al., 2017). 
Relationships have also been established between workplace isolation and employee behavior like turnover intention (Golden et al., 2008; Mulki \& Jaramillo, 2011; Orhan et al., 2016), intention to stay (O'Donnell et al., 2010); team work (Itani et al., 2019); extra-role behavior (Mulki \& Jaramillo, 2011), employee voice and silence (McFadden \& CrowleyHenry, 2018), deviant behavior (Mangles et al., 2016), motivation for change (Liston-Heyes \& Juillet, 2019) and organization citizenship behavior (Kane, 2014).

Further to this, relations have also been found between workplace isolation and job performance (Chen \& Kao, 2012; Dolan, 2011; Golden et al., 2008; Itani et al., 2019; Mulki et al., 2008; Orhan et al., 2016). Workplace isolation has also been shown to impact occupational stress (Dussault et al., 1999), morbidity and mortality (Johnson et al., 1989), psychological strain (Bentley et al., 2016) and overall well-being (Yang, 2017).

Scholars have also examined several mediating variables in workplace isolation-outcome relationship. Mulki et al. (2008) found that trust in leadership and trust in co-worker fully mediate the relationship between workplace isolation and satisfaction with leader and coworker, which in turn influences organizational commitment and organizational commitment in turn impacts job performance. Bartel et al. (2012) found that perceived respect mediates the relationship between physical isolation and organizational commitment relationship amongst employees in consulting industry. From their empirical findings they concluded that physical isolation reduced perceived respect, which negatively influenced organizational identification. Gracia et al. (2017) in their empirical research on commercial cleaners found that pro-social behavior and stigmatization mediate the relationship between social isolation and engagement and burnout such that social isolation reduces the pro-social behavior which negatively influences engagement and social isolation increases perceived stigmatization which in turn increases exhaustion. Liston-Heyes and Juillet (2019) found that engagement with professional body partially mediates the relationship between organizational professional isolation and motivation for change amongst public sector internal auditors.

Further to this, Bentley et al. (2016) found that when perceived support (perceived organizational support and perceived social support) is high, workplace isolation is less and workplace isolation in turn mediates the relationship between perceived support and psychological strain and job satisfaction.

\subsection{Moderators of Workplace Isolation}

Several moderating variables have been explored in antecedent-workplace isolation relationship. Johnson et al. (1989) found that blue collar employees were at a higher risk of morbidity and mortality caused due to combined effect of social isolation and job strain (psychological job demands and work control) than white collar workers. Dussault et al. (1999) found that gender moderated the relationship between isolation and occupational stress, women were more negatively impacted by isolation on occupational stress than men. Kurland and Cooper (2002) found that high frequency of teleworking; long-term teleworking and short duration of working with organization can lead to professional isolation. Munir et al. (2016) found that impact of transformational leadership and interpersonal trust on reducing isolation of the salesperson was stronger if their self-efficacy was high as compared to low. Golden et al. (2008) found that more face-to-face interaction and access to communication enhancing technology reduces the negative impact of professional isolation on job performance, whereas more time spent on telecommuting increases the negative impact of professional isolation on job performance.

Bentley et al. (2016) found that telework intensity and type of telework moderate the relationship between isolation and outcome relationship (psychological strain and job satisfaction), with those having low intensity telework (few hours a week) and hybrid telework 
(one or more days per week) have reduced impact of isolation on work outcomes. McFadden and Crowley-Henry (2018) in a recent qualitative study on workplace isolation on LGBT employees found that though sexual orientation can cause isolation and negatively impact employee voice and support but LGBT network can moderate this relationship i.e., involvement in LGBT network can reduce the impact of isolation in silencing employee voice for some of the LGBT employees. Orhan et al. (2016) found that with increase in task virtuality workplace social isolation also increases. Additionally, they also indicated that task virtuality has more impact on isolation and in turn on turnover intention than team virtuality.

\section{SYNTHESIZING FRAMEWORK AND FUTURE RESEARCH DIRECTIONS}

With the increasing trend of new work arrangements, workplace isolation concept has gained attention. Researchers have cautioned about the negative impact of workplace isolation. We conducted a review on the existing literature to synthesize the existing knowledge in this area. Based on our review we found that this is an under-researched area that needs attention of scholars. We now present synthesis of our review:

We found several antecedents, mediators, moderator and outcome variables that have significant relationship with workplace isolation. However, as pointed out earlier cent-percent of the quantitative studies reviewed were cross-sectional. Hence, there is an urgent need to conduct longitudinal studies to establish causality among the variables. Similarly, large part of the existing research has been done in the U.S., investigations in other countries can add interesting findings to the existing body of literature.

With respect to conceptualization and definition of workplace isolation, we argue that it is a multi-dimensional construct including lack of support, lack of interaction, lack of learning opportunity, lack of developmental opportunities and physical isolation. We advocate that though workplace isolation should be examined as a higher-order construct (comprising five dimension), yet there is a need to give attention to all the sub-dimensions of workplace isolation for a better understanding of isolation concept in different work settings (like experience of isolation of teachers would be very different from salesperson, also from those who work-fromhome and those that have been socially marginalized because of the group characteristics to which they belong).

Another reason that weighs in favor of our argument to have both consolidate (consider it as a higher order construct) and discrete sub-dimensions of workplace isolation, is the availability of myriad of measures that have been used in workplace isolation research. Amongst the 27 quantitative researches included in this review, 15 instruments have been used to measure workplace isolation. Marshall et al. (2007) 10-item workplace isolation has been most frequently used (seven times). However, there is no consensus on universally accepted scale for measuring workplace isolation. We call for research to develop new measure for workplace isolation that includes all these sub-dimensions. We strongly urge scholars to fill in this gap.

Based on the review, we classified the antecedents that can impact workplace isolation into three categories - work environment related, leadership/supervisor/ coworker related and job related. There is a lack of research evidence on the impact of person related variables on workplace isolation. It would also be interesting to explore the role of personal dispositions on workplace isolation. Also, future research can examine the combined effect of work environment variables, leadership variables and job variables as antecedent on workplace isolation can be considered. Our review also indicated that workplace isolation can lead to deviant work behavior, research evaluating the mechanism underpinning this relationship can also be explored. In our review we found that workplace isolation can have impact on myriad 
of outcome variables including affect, attitude, behavior and well-being. Workplace isolation can be considered as an experience that invokes emotions. Hence, mechanisms involved in the relationship between workplace isolation and outcomes can be explored through the lens of Affective Events Theory (Weiss \& Cropanzano, 1996).

Some other potential areas for future research are now discussed. Relationship between social isolation and health among elderly population, youth and children is well established (Leigh-Hunt et al., 2017). We recommend examining the framework of workplace isolation and health in the organizational studies. Qualitative studies have highlighted the association between workplace isolation and emotions (Mann \& Holdsworth, 2003; Mann et al., 2000). Exploring empirical evidence in this relationship can provide statistical support to these findings and pave way for exploring stressor emotion models (Spector \& Goh, 2001) in workplace isolation context.

There is a dearth of research in workplace isolation and group dynamic framework. We call for a research on impact of workplace isolation on group dynamics. Creativity is a desired outcome variable as it provides sustainable competitive advantage. We predict that workplace isolation as a stressor can negatively impact creativity. Amongst the papers we reviewed there was no empirical evidence to this important variable. We urge future researchers to explore its relationship with workplace isolation. Workplace isolation needs to be examined in the career studies too. Our review indicates that professional isolation occurs due to reduced opportunity for learning and career advancement. It would be of great interest to explore how professional isolation is linked to various career outcome variables like career success. Association between career adaptability and workplace isolation is another area for potential advancement.

There are some moderating variables that have been examined and several others that can be examined in future research, we now discuss them. Future research can examine workplace isolation and antecedent/outcome relationships amongst various types of groups like millennial, ethical minority groups, expatriates, client service work, C-suite executives. With rise in remote working amongst IT professionals, non-banking financial companies, these groups also need to be closely examined. There is also a difference in the degree of isolation at work depending on the frequency of virtual working (Bailey \& Cooper, 1999; Kurland \& Cooper, 2002; Golden et al., 2008; Davis \& Cates, 2013; Kane 2014; Gainey et al., 1999). Future researches need to compare and contrast the difference in workplace isolation and its impact on antecedent/outcome variables for differential frequency of virtual working. We sincerely hope that such examination makes a suggestive optimum frequency of teleworking.

Studies have also called for future research on impact of various demographic variables like age, gender, tenure, education, number of children, number of days spent telecommuting, parttime vs. full-time employment (Mulki \& Jaramillo, 2011; Davis \& Cates, 2013; Garcia et al., 2017, Wang et al., 2020); salary (Wang et al., 2020) on workplace isolation antecedent/ outcome relationships. Impact of tenure of telework arrangement; type of communication technology used for interaction, preference for flexibility and choice of work location; (Davis \& Cates, 2013; Kane, 2014; Munir et al., 2016; Wang et al., 2020) can also throw some meaningful insights. Organizational variables like formalized organization procedures especially for promotion (Cooper \& Kurland, 2002) can also be examined as potential moderator for workplace isolation-outcome relationship. Certain variables outside organizational control like interaction on out of work scope with individuals in co-working space, extent of emotional support outside work, preexisting emotional bonds with colleagues (Orhan, et al. 2016; Wang et al., 2020) can also be examined.

Peplau and Perlman (1982) suggested that professional isolation can be caused by individual's predisposition. In our review we found that only four predispositions were examined: self-efficacy (Mulki and Jaramillo, 2011; Munir et al., 2016), defensive pessimism 
(Bunjak \& Crene, 2018), proactive personality and need-to-belong. While self-efficacy and defensive pessimism had statistically significant moderating roles in isolation-outcome relationships, the remaining two personality variables i.e., proactive personality and need-tobelong, did not have statistical significant moderating effect in workplace isolation-outcome relationship (Kane, 2014), however future research on these personality variables must be explored. Predispositions like autonomy, personality traits like extroversion, consciousness, locus of control have been found to be an important moderator in several behavioral streams and examination of these variables in workplace isolation studies can provide interesting expansion of workplace isolation literature. Personal strengths like psychological capital, hardiness and gratitude have been found as significant potential moderators in work stressor and outcome association. Examining these personal strengths as potential moderators in workplace isolation and outcome variables can be a fruitful pursuit.

\section{CONCLUSION}

The extant literature on workplace isolation has yielded insights into what can cause workplace isolation (including job characteristics, supervisor and coworker support and other organizational variables), what is its impact on outcome variables (including attitude, behavior, performance and well-being) and various mechanisms through which it can impact outcome variables. This field of research is still in its nascent stage in the organizational literature, with immense potential to drive new and exciting directions. The purpose of the current review is to bring coherence to the disparate literature by uncovering the causes, mechanism and outcomes underpinning workplace isolation. With the rising popularity of telecommuting, available technologies to support this working environment, this mode of work is being considered as future of work. Workplace isolation can also occur amongst those who work in traditional worksettings and have implication on outcome variables. The time is ripe for a deep-dive into this area of research and it is our sincere hope that this review can provide an organizing framework and encourage scholars to understand, explore and broaden the literature on workplace isolation.

\section{REFERENCES}

[1] Abad, C., Fearday, A., \& Safdar, N. (2010). Adverse effects of isolation in hospitalised patients: a systematic review. Journal of Hospital Infection, 76(2), 97-102.

[2] Bartel, C. A., Wrzesniewski, A., \& Wiesenfeld, B. M. (2012). Knowing where you stand: Physical isolation, perceived respect, and organizational identification among virtual employees. Organization Science, 23(3), 743-757.

[3] Baruch, Y. (2000). 'Teleworking: Benefits and Pitfalls as Perceived by Professionals and Managers', New Technology, Work and Employment, 15(1), 34-48.

[4] Bentley, T. A., Teo, S. T. T., McLeod, L., Tan, F., Bosua, R., \& Gloet, M. (2016). The role of organisational support in teleworker wellbeing: A socio-technical systems approach. Applied Ergonomics, 52, 207-215.

[5] Bostanci, A. B. (2013), The role of positive emotion towards work as a mediator in the relationship between organizational responsiveness towards teachers and isolation in professional life. Educational Research and Reviews, 8(8), 367.

[6] Briner, R. B., \& Denyer, D. (2010). Systematic review and evidence synthesis as a practice and scholarship tool. In D. Rousseau (Ed.), Handbook of evidenced-based management: companies, classrooms, and research, (pp. 328-347). Oxford: Oxford University Press.

[7] Bunjak, A., \& Černe, M. (2018). The Role Of Leader-Follower Defensive Pessimism (In)Congruence In Fostering Perceptions Of Followers' Isolation, Economic and Business Review for Central And South - Eastern Europe. Economic and Business Review, 20(1), 129157. 
[8] Chen, C. F., \& Kao, Y. L. (2012). Investigating the antecedents and consequences of burnout and isolation among flight attendants. Tourism Management, 33(4), 868-874.

[9] Cooper, C. D., \& Kurland, N. B. (2002). Telecommuting, professional isolation, and employee development in public and private organizations. Journal of Organizational Behavior: The International Journal of Industrial, Occupational and Organizational Psychology and Behavior, 23(4), 511-532.

[10] Connaughton, S. L. \& Daly, J. A. (2004). Identification with leader: A comparison of perceptions of identification among geographically dispersed and co-located teams. Corporate Communications: An International Journal, 9(2), 89-103.

[11] Davis, R., \& Cates, S. (2013), The Dark Side of Working in a Virtual World: An Investigation of the Relationship between Workplace Isolation and Engagement among Teleworkers. Journal of Human Resource and Sustainability Studies, 1, 9-13.

[12] de Jong Gierveld, J., Van Tilburg, T., \& Dykstra, P. A. (2006). Loneliness and social isolation. In A. Vangelisti \& D. Perlman (Eds), Handbook of personal relationships (pp.485500). Cambridge: Cambridge University Press.

[13] Dean, D. G. (1961). Alienation: Its meaning and measurement. American Sociological Review, 26(5), 753-758.

[14] Delanoeije, J., Verbruggen, M., \& Germeys, L. (2019). Boundary role transitions: A day-to-day approach to explain the effects of home-based telework on work-to-home conflict and home-towork conflict. Human Relations, 72(12), 1843-1868.

[15] Dolan, V. (2011). The isolation of online adjunct faculty and its impact on their performance. International Review of Research in Open and Distributed Learning, 12(2), 6277.

[16] Doğan, T., Çetin, B., \& Sungur, M. Z. (2009). İş yaşamında yalnızlık ölçeği Türkçe formunun geçerlilik ve güvenilirlik çalışması [Scale of loneliness in working life - validity and reliability study of Turkish form]. Anadolu Psikiyatri Dergisi (Anadolu Psychiatr. Journal), 10, 271-277.

[17] Dussault, M., \& Barnett, B. G. (1996). Peer-assisted leadership: Reducing educational managers' professional isolation. Journal of Educational Administration, 34(3), 5-14.

[18] Dussault, M., Deaudelin, C., Royer, N., \& Loiselle, J. (1999). Professional isolation and occupational stress in teachers. Psychological Reports, 84(3), 943-946.

[19] Gainey, T. W., Kelley, D. E., \& Hill, J. A. (1999). Telecommuting's impact on corporate culture and individual workers: Examining the effect of employee isolation. SAM Advanced Management Journal, 64(4), 4.

[20] Gajendran, R. S., \& Harrison, D. A. (2007). The good, the bad, and the unknown about telecommuting: meta-analysis of psychological mediators and individual consequences. Journal of Applied Psychology, 92(6), 1524.

[21] Gallatin, K. A. (2018). Teleworker Isolation: Possible Effects of Workplace Relationships and Support (Doctoral dissertation, Baker College (Michigan)).

[22] Garcia, A., Bentein, K., Herrbach O. \& Guerrero S. (2017). How does social isolation in a context of dirty work increase emotional exhaustion and inhibit work engagement? A process model. Personnel Review, 46(8), 1620-1634.

[23] Golden, T. D., Veiga, J. F., \& Dino, R. N. (2008), The impact of professional isolation on teleworker job performance and turnover intentions: Does time spent teleworking, interacting face-to-face, or having access to communication-enhancing technology matter?. Journal of Applied Psychology, 93(6), 1412.

[24] Harrington, S. J., \& Santiago, J. (2006), Organizational culture and telecommuters' quality of work life and professional isolation. Communications of the IIMA, 6(3), 1.

[25] Holt-Lunstad, J., Smith, T. B., Baker, M., Harris, T., \& Stephenson, D. (2015). Loneliness and social isolation as risk factors for mortality: a meta-analytic review. Perspectives on Psychological Science, 10(2), 227-237.

[26] Huws, U. (1984). The new homeworkers: New technology and the changing location of whitecollar work (No. 28). Low Pay Pamphlet Number 28, London: Low Pay Unit.

[27] Hawthorne (2006), Measuring social isolation in older adults: development and initial validation of friendship scale. Social Indicators Research, 77(3), 521-548. 
[28] ILO (International Labour Organisation) (2020). Teleworking during the COVID-19 pandemic and beyond: a practical guide. International Labour Office, Geneva. Retrieved from https://www.ilo.org/wcmsp5/groups/public/ed_protect/protrav/travail/documents/publication/ wcms_751232.pdf.

[29] Itani, O. S., Jaramillo, F., \& Chonko, L. (2019), Achieving top performance while building collegiality in sales: It all starts with ethics. Journal of Business Ethics, 156(2), 417-438.

[30] Johnson, J. V., Hall, E. M., \& Theorell, T. (1989). Combined effects of job strain and social isolation on cardiovascular disease morbidity and mortality in a random sample of the Swedish male working population. Scandinavian Journal of Work, Environment \& Health, 271-279.

[31] Kane, L. M. (2014). Telework and organizational citizenship behaviors: The underexplored roles of social identity and professional isolation (Doctoral dissertation, City University of New York).

[32] Kurland N.B. \& Bailey D.E. (1999). When workers are here, there, and everywhere: a discussion of the advantages and challenges of telework. Organizational Dynamics, 28(2), 53-68

[33] Kurland, N. B., \& Cooper, C. D. (2002). Manager control and employee isolation in telecommuting environments. The Journal of High Technology Management Research, 13(1), 107-126.

[34] Leiter, J. (1985). Work Alienation in the Textile Industry: Reassessing Blauner. Work and Occupations, 12, 479-498.

[35] Leigh-Hunt, N., Bagguley, D., Bash, K., Turner, V., Turnbull, S., Valtorta, N., \& Caan, W. (2017). An overview of systematic reviews on the public health consequences of social isolation and loneliness. Public Health, 152, 157-171.

[36] Liston-Heyes, C., \& Juillet, L. (2019). Employee isolation and support for change in the public sector: a study of the internal audit profession. Public Management Review, 21(3), 423-445.

[37] Mangles, P., Khanin, D., \& Guzman, I. R. (2016). Perceived isolation, its impact on professional deviance and deviant workplace behaviors. In Academy of management proceedings (Vol. 2016, No. 1, p. 15513). Briarcliff Manor, NY 10510: Academy of Management.

[38] Mann, S., \& Holdsworth, L. (2003). The psychological impact of teleworking: stress, emotions and health. New Technology, Work and Employment, 18(3), 196-211.

[39] Mann, S., Varey, R., \& Button, W. (2000). An exploration of the emotional impact of teleworking via computer-mediated communication. Journal of Managerial Psychology, 15 (7), 668-690.

[40] Marshall, G. W., Michaels, C. E., \& Mulki, J. P. (2007). Workplace isolation: Exploring the construct and its measurement. Psychology \& Marketing, 24(3), 195-223.

[41] McFadden, C., \& Crowley-Henry, M. (2018). 'My People': the potential of LGBT employee networks in reducing stigmatization and providing voice, The International Journal of human resource management, 29(5), 1056-1081.

[42] Mulki, J. P., \& Jaramillo, F. (2011). Workplace isolation: salespeople and supervisors in USA. The International Journal of Human Resource Management, 22(4), 902-923.

[43] Mulki, J. P., Locander, W. B., Marshall, G. W., Harris, E. G., \& Hensel, J. (2008). Workplace isolation, salesperson commitment, and job performance, Journal of Personal Selling \& Sales Management, 28(1), 67-78.

[44] Munir, Y., Sadiq, M., Ali, I., Hamdan, Y., \& Munir, E. (2016). Workplace isolation in pharmaceutical companies: Moderating role of self-efficacy, Social Indicators Research, 126(3), 1157-1174.

[45] Nicholson, N. R. (2012). A review of social isolation: an important but underassessed condition in older adults. The journal of primary prevention, 33(2-3), 137-152.

[46] Nilles, J. (1975). Telecommunications and organizational decentralization. IEEE Transactions on Communications, 23(10), 1142-1147.

[47] O'Donnell, C. A., Jabareen, H., \& Watt, G. C. (2010). Practice nurses' workload, career intentions and the impact of professional isolation: A cross-sectional survey. $B M C$ Nursing, 9(1), 2.

[48] Orhan, M. A., Rijsman, J. B., \& Van Dijk, G. M. (2016). Invisible, therefore isolated: Comparative effects of team virtuality with task virtuality on workplace isolation and work outcomes. Revista de Psicología del Trabajo y de las Organizaciones, 32(2), 109-122. 
[49] Peplau, L. A., \& Perlman, D. (1982). Perspective on loneliness. In L. A. Peplau \& D. Perlman (Eds.), Loneliness: A sourcebook of current theory, research and therapy (pp. 1-18). New York: John Wiley and Sons.

[50] Riggle, R. J. (2007). The impact of organizational climate variables of perceived organizational support, workplace isolation, and ethical climate on salesperson psychological and behavioral work outcomes (Doctoral dissertation, University of South Florida).

[51] Riggle, R. J., Solomon, P., \& Artis, A. (2015). The impact of perceived organizational support on salesperson psychological and behavioral work outcomes. International Journal of Management Research and Business Strategy, 4(1), 134-147.

[52] Russell, D. (1996). The UCLA Loneliness Scale (Version 3): Reliability, validity, and factor structure. Journal of Personality Assessment, 66(1), 20-40.

[53] Russell, D., Peplau, L.A., \& Cutrona, C. E.(1980).The Revised UCLA Loneliness Scale: Concurrent and discriminant validity evidence. Journal of Personality and Social Psychology, 39(3), 472-480.

[54] Spector, P. E., \& Goh, A. (2001). The role of emotions in the occupational stress process. In P. L. Perrewé \& D. C. Ganster (Eds.). Research in occupational stress and well-being: exploring theoretical mechanisms and perspectives (Vol.1, pp.195-232). Greenwich, CT: JAI.

[55] Stephenson, L. E., \& Bauer, S. C. (2010), The role of isolation in predicting new principals' burnout. International Journal of Education Policy and Leadership, 5(9), 1-17.

[56] Sulu, S., Ceylan, A., \& Kaynak, R. (2010), Work alienation as a mediator of the relationship between organizational injustice and organizational commitment: Implications for healthcare professionals. International Journal of Business and Management, 5(8), 27-38.

[57] Taha, L. H., \& Caldwell, B. S. (1993). Social isolation and integration in electronic environments. Behaviour \& Information Technology, 12(5), 276-283.

[58] Teo, T. S. H., Lim, V. K. G. \& Wai, S. H. (1998). An empirical study of attitudes towards teleworking among Information Technology (IT) personnel. International Journal of Information Management, 18(5), 329-343.

[59] Van Acker, W., Bouckaert, G., Frees, W., Nemec, J., Orviska, M., Lawson, C., ... Flemig, S. (2015). Mapping and Analysing the Recommendations of Ombudsmen, Audit Offices and Emerging Accountability Mechanisms. Learning from innovation in Public Sector Environments (LIPSE), Rotterdam, The Netherlands.

[60] Wang, W., Albert, L. \& Sun, Q. (2020). Employee isolation and telecommuter organizational commitment. Employee Relations, 42(3), 609-625.

[61] Yang, C. (2017). The influence of supervisor cultural intelligence on employee well-being. In Academy of management proceedings (Vol. 2017, No.1, p.13364). Academy of Management, Briarcliff Manor, NY.

[62] Yang, M. J., Yang, M. S., \& Kawachi, I. (2001). Work experience and drinking behavior: alienation, occupational status, workplace drinking subculture and problem drinking. Public Health, 115, 265-271. 